Сартори П., Шаблей П. Эксперименты империи: адат, шариат и производство знаний в Казахской степи. М.: Новое литературное обозрение, 2019. 280 с. (Серия «Historia Rossica»)

\author{
Д.3. Марданова (рецензент) \\ Институт истории имени Ш. Марджани Академии наук Республики Татарстан; \\ 420111, Россия, Казань, ул. Батурина, 7A; dinara.mardanova@gmail.com

\section{Sartori, P. and Shabley, P. Experimenty imperii: adat, shariat i proizvodstvo znaniya v Kazahskoy stepi [Empire Experiments: Adat, Sharia and Knowledge Production in the Kazakh Steppe]. Moscow: Novoe literaturnoe obozrenie Publ., 2019, 280 p. (Series: "Historia Rossica")}

\author{
Dinara Z. Mardanova (rewiever)
}

Sh. Mardjani Institute of History Academy of Sciences of the Republic of Tatarstan; 7A Baturina Str., Kazan, 420111, Russia; dinara.mardanova@gmail.com

Казахская степь характеризуется богатством культур проживающих здесь народов, разнообразием форм их взаимодействия и контактов. Данное обстоятельство влияло на историю этих территорий, делая опыт межэтнических отношений уникальным, в том числе в таком его аспекте, как производство знания. Активное участие в этом процессе играла Российская империя, непосредственно определявшая и направлявшая его в нужное, с точки зрения государственного интереса, русло. Показательным примером имперского влияния на производство знания в Казахской степи стал процесс кодификации обычного права, подробно рассмотренный известными специалистами по истории мусульманских обществ, истории Центральной Азии и исламскому праву в Российской империи Паоло Сартори и Павлом Шаблеем ${ }^{1}$ в совместной монографии «Эксперименты империи: адат, шариат и производство знаний в Казахской степи», вышедшей в издательстве «Новое литературное обозрение» в 2019 г.

В центре монографии проблема субъективности знания и множественности имперских ситуаций. По мнению авторов, империя конструировала новые формы знаний либо же заимствовала опыт других колониальных держав. В качестве предмета исследования рассматривается процесс кодификации местного права в ходе присоединения Казахской степи к Российской империи в 60-70-е гг. XIX в., анализируется соотношение в нем норм адата и шариата. Как утверждают авторы, организованная с целью наладить управление этими территориями кодификация прохо-

(C) Марданова Д.3., 2020

(c) (1) This work is licensed under a Creative Commons Attribution 4.0 International License https://creativecommons.org/licenses/by/4.0/

${ }^{1}$ Паоло Сартори - PhD, старший научный сотрудник Института иранистики Академии наук Австрии; Павел Шаблей - к.и.н., доцент Костанайского филиала Челябинского государственного университета. 
дила в несколько этапов. Вначале предполагалось изучить местные традиции; затем их следовало, с одной стороны, очистить от «диких обычаев», а, с другой - оградить от исламского влияния; на завершающем этапе «очищенный» свод требовалось привести к общей системе.

Кодификация входила в комплекс действий по адаптации региона к нуждам колониального управления и носила весьма противоречивый характер, что было вызвано различными факторами. В частности, многочисленные трудности, с которыми столкнулись его организаторы и исполнители, в числе которых оказались чиновники разных уровней, востоковеды и местные казахи, - нередко были связаны с существующим многообразием представлений о казахском праве, его структуре, составе, соотношении в нем адата и шариата, формате кодификации. Отсутствие единства порождало противоречия, различные дискуссии и формы взаимодействия. Наряду с человеческим фактором сильное влияние на характер кодификации оказывали политические процессы и культурные изменения, происходившие в Казахской степи с конца XVIII в. до середины 1860-х гг. В частности, противопоставление норм адата и шариата нередко было связано с восприятием ислама как помехи на пути реализации реформ Российской империи в Казахской степи.

Бесспорным достоинством монографии является то, что на примере кодификации местного права авторы анализируют не только специфические правовые вопросы, но и выходят на более широкий спектр проблем имперской политики, культурных изменений и административного регулирования в разных регионах Казахской степи.

География исследования не ограничивается событиями одной области, в связке рассматриваются Оренбург, Омск и Сыр-Дарьинская военно-укрепленная линия, проводятся параллели с Северным Кавказом и с опытом других колониальных империй.

В качестве теоретической методологической рамки предлагается термин правовая гибридность, которая исследуется в связи с концепцией ориентализма, герменевтическим анализом, теорией фронтира. Выбранный ракурс позволяет почувствовать динамику колониальной истории, разобраться в ее дискурсивных и контекстуальных особенностях.

Бесспорным достоинством монографии является обширная источниковая база. В основе исследования богатый архивный материал из фондохранилищ Российской Федерации, Республик Казахстан и Узбекистан. Среди них - Российский государственный исторический архив, Архив Санкт-Петербургского института истории Российской академии наук, Архив востоковедов Института восточных рукописей РАН, Отдел рукописей Российской национальной библиотеки, Национальный архив Республики Татарстан, Отдел рукописей и редких книг научной библиотеки Казанского федерального университета, Архив внешней политики Российской империи, Государственный архив Оренбургской области, Центральный исторический архив Республики Башкортостан, Исторический архив Омской области, Центральный государственный архив Республики Казахстан, Государственный архив ВосточноКазахстанской области, Центральный государственный архив Республики Узбекистан. Наряду с архивными источниками авторы обращаются также к опубликованным материалам на английском, казахском, русском и татарском языках. Привлечение богатого фактического материала позволяет не только рассмотреть в исторической перспективе процесс кодификации казахского обычного права, но через анализ дискуссий вокруг шариата и адата также выйти на более широкий спектр проблем имперской политики в разных регионах Казахской степи, когда сама правовая история оказывалась частью более широкого круга вопрос о праве, колониализме и имперской истории.

Книга включает в себя введение, четыре главы, заключение, шесть приложений, глоссарий, весьма обширную библиографию, список карт, фотографий и иллюстраций, также имеется список сокращений и именной указатель, которым завершается книга. 
Во введении (С. 5-23) очерчивается теоретическая рамка исследования. Под авторскую ревизию попадает историография правового плюрализма. В качестве альтернативного варианта данному подходу правовую ситуацию Казахской степи в XIX - начале XX в. предлагается рассматривать как ситуацию «правовой гибридности», а нижнее и среднее течение Сырдарьи в период с 1853 по 1864 гг. - не как границу или военный предел, а как фронтир, понимаемый как сложная контактная зона и анализируемый как процесс и контекст.

Первая глава (С. 24-50) посвящена истории Казахской степи в колониальном контексте в XVIII-XIX вв. Подробно рассматриваются практики имперского конструирования знаний и влияние этих практик на особенности управления регионом.

Право рассматривается как постоянно трансформирующийся механизм, через который формируется имперский опыт по управления окраинами. Авторы предлагают уйти от устоявшегося понимания колониализма, часто рассматриваемого преимущественно в виде адаптации колонизируемых к существующему политическому порядку. Вместо этого предлагается взглянуть на колониализм через сложную социальную динамику, когда менялось не только сознание и поведение субъектов колониального управления, но и поведение самих чиновников, когда колониальный режим вынужден был постоянно производить новые конструкции знаний и опыта для управления людьми и территориями.

Во второй главе (С. 51-86) рассматриваются попытки кодифицировать казахское обычное право в Оренбурге и Омске, предполагавшие «очищение» права от «диких обычаев», в том числе исламских элементов, недопустимых с точки зрения государственных интересов. Анализируются причины неудач и ошибок российских властей при кодификации права в Казахской степи и на Кавказе, опыт Российской империи сравнивается с аналогичным опытом других колониальных империй (с британским опытом в Индии, французским - в Алжире). Кроме того, на примере омского и оренбургского проектов анализируются примеры «работ над ошибками».

Третья глава (С. 87-157) посвящается сборнику обычного права, подготовленного востоковедом, чиновником Азиатского музея МИД и ОПК, начальником сырдарьинских казахов - И.Я. Осмоловским. Вызвавший множество дискуссий среди чиновников разного управленческого уровня, данный сборник подорвал прежнюю систему колониальных знаний о Казахской степи, основанную на противопоставлении адата и шариата, привнеся идею о том, что адат является частью обширной исламской правовой культуры. Помимо сборника Осмоловского, третья глава интересна также представленным в ней анализом влияния на право социально-политических процессов. Так, развитие науки, всплеск научного интереса к различным инородческим обществам, развитие этнографии и востоковедения, как считают авторы, способствовали формированию научных школ, что, в свою очередь, оказало влияние на появление новых сборников права. Среди них - 1) туземные, подготовленные представителями «туземной» интеллигенции и 2) востоковедные, созданные профессиональными востоковедами.

В четвертой главе (С. 158-228) анализируется ситуация Сырдарьинского фронтира. В рамках теории фронтира рассматривается развитие имперской политики в связи с завоеванием нижнего и среднего течения Сырдарьи и образованием здесь сложной контактной зоны. Ее особенность состояла в срединном расположении относительно империи и центральноазиатских ханств, с одной стороны, и казахских кочевых групп - с другой. К этому времени сама империя уже не стремилась к кодификации обычного права, но трансформация местной правовой системы продолжалась: наряду с адатом и российскими законами, по прагматическим соображениям чиновники апеллировали также к нормам шариата. Интересной исследовательской находкой этой главы является раздел «Соблазны фронтира: курьезы имперской био- 
графии», в котором через биографии персонажей Сырдарьинского фронтира, М.Б. Первухина и Ермухаммеда Касымова, частично И.Я. Осмоловского, авторы анализируют политическую ситуацию Сырдарьи.

В шести приложениях к книге имеется материал по обычному праву ${ }^{2}$, старые карты региона; научно-справочный аппарат.

Исследование с новой стороны показало сущность процесса кодификации обычного казахского права в условиях Российской империи. Репрезентативная источниковая база, критическое отношение к историографической традиции, новые методологические ракурсы - все это позволило авторам показать процесс кодификации во всей его полноте. Привлечение материалов на местных языках дало возможность услышать голоса обеих сторон, империи и местного населения, и показало сложную мозаичность происходящих событий. Как было справедливо отмечено, процесс имел разнонаправленный характер и в нем принимали участие не только имперские акторы, но также и представители местных элит. В монографии поэтапно показано влияние на кодификацию чиновников разных уровней, изменения в стратегиях кодификации в зависимости от политической, экономической и культурной ситуаций.

Без сомнения, авторами была проведена внушительная работа по систематизации имеющихся материалов по данной проблеме. Интересным ходом стало рассмотрение окружающих политических процессов через биографии главных героев.

В заключение необходимо еще раз подчеркнуть значимость рецензируемой монографии «Эксперименты империи: адат, шариат и производство знаний в Казахской степи» именно с точки зрения нового взгляда на, казалось бы, привычные и знакомые процессы и явления. Исследование рассчитано на историков и всех интересующихся историей Российской империи и Казахской степи, вопросами права и фронтирными зонами. Монография существенно расширяет рамки исследований в вопросах субъективности и производства знания, правовой гибридности, правовой кодификации и культурной ассимиляции окраинных земель; знакомит с широким кругом архивных и опубликованных источников и научной литературой; приглашает к дальнейшим исследованиям окраинных территорий Российской империи, теории фронтира, к изучению имперских биографий и имперских политических акторов, а также к другим исследовательским вопросам и темам.

В целом хотелось бы поблагодарить авторов и пожелать им дальнейших интересных исследований.

Рукопись поступила: 3 мая 2020 г.

Submitted: 3 May 2020

\section{Информация об авторе / Information about the author}

Марданова Динара Замировна, научный сотрудник Института истории имени Ш. Марджани Академии наук Республики Татарстан.
Dinara Z. Mardanova, Researcher of Sh. Marjani Institute of the Academy of Sciences of the Republic of Tatarstan.

2 Приложения: Сборник киргизских обычаев, имеющих в Орде силу закона. Факсимиле первой и второй страницы второй части; рапорт председателя Оренбургской пограничной комиссии В.В. Григорьева от 29 мая 1857 г.; Предписание оренбургского и самарского генерал-губернатора В. Перовского И. Осмоловскому об обязанностях при назначении на должность; Рапорт управляющего шомекеевским родом подполковника султана Ермухаммеда Касымова (перевод со староказахского и оригинал); Рапорт есаула Карамышева; Карты. 